" Modernité et changement religieux en Iran », in : Azadeh Kian-Thiébaut, dir., L'Iran : le régime conforté. Les Cahiers de l'Orient, $\mathrm{n}^{\circ} 79,3^{\mathrm{e}}$ trim. 2005, pp. 57-74.

\title{
Philippe Rochard
}

\section{OpenEdition}

\section{Journals}

Édition électronique

URL : http://journals.openedition.org/abstractairanica/20421

DOI : 10.4000/abstractairanica.20421

ISSN : 1961-960X

Éditeur :

CNRS (UMR 7528 Mondes iraniens et indiens), Éditions de l'IFRI

Édition imprimée

Date de publication : 15 mai 2007

ISSN : 0240-8910

\section{Référence électronique}

Philippe Rochard, « « Modernité et changement religieux en Iran », in : Azadeh Kian-Thiébaut, dir., L'Iran : le régime conforté. Les Cahiers de l'Orient, $n^{\circ} 79$, $3^{e}$ trim. 2005, pp. 57-74. », Abstracta Iranica [En ligne], Volume 28 | 2007, document 405, mis en ligne le 18 septembre 2007, consulté le 25 septembre 2020. URL : http://journals.openedition.org/abstractairanica/20421 ; DOI : https://doi.org/10.4000/ abstractairanica. 20421

Ce document a été généré automatiquement le 25 septembre 2020.

Tous droits réservés 


\title{
« Modernité et changement religieux en Iran ", in : Azadeh Kian- Thiébaut, dir., L'Iran : le régime conforté. Les Cahiers de l'Orient, $\mathrm{n}^{\circ} 79$, $3^{\text {e }}$ trim. 2005, pp. 57-74.
}

\author{
Philippe Rochard
}

1 Cet article vise à mieux comprendre les formes nouvelles de religiosité chez les jeunes en Iran (à cette fin, près de 200 entretiens ont été menés auprès de 350 jeunes âgés de 18 à 30 ans à Téhéran, Qazvin et Qom). Après une longue synthèse des analyses disponibles sur les transformations des religiosités traditionnelles, l'A. aborde l'objet de son enquête en s'attachant à en observer différentes dimensions, pour enfin livrer sa "première lecture partielle et provisoire de la subjectivité religieuse des jeunes » (p. 69).

2 L'A. relève que «l'anti-religiosité, l'irréligiosité ou la religiosité instrumentale (noncroyant mais incluant la religion comme une stratégie politique) sont des phénomènes peu répandus chez les jeunes interrogés ", au profit d'une "religiosité populaire ou coutumière " (croyants non-pratiquants). Il constate une "diversité complexe» des expériences religieuses, dont il énumère plusieurs faits saillants: phénomènes de syncrétisme et d'hybridation (shi'ite croyant en la réincarnation...), corrélation entre le degré de foi et la pratique effective, sélection des dogmes suivis par les croyants au détriment de la totalité du canon, baisse des activités proprement religieuses (fréquentation des mosquées et des associations religieuses...) au profit de comportements religieux individuels, etc. L'A. note un rejet massif des directives du nouveau pouvoir en matière religieuse, qu'il explique par la pression conjointe de la rencontre de cette foi avec le monde moderne et par les effets dissuasifs «des politiques autoritaires érigées au nom de la religion» (p. 73) qui poussent les jeunes 
Iraniens vers « des sources différentes pour donner un sens à leur vie et définir leur identité religieuse » (p. 74).

3 L'A. a l'immense mérite d'explorer, sur un terrain que l'on devine difficile, un objet à la fois labile, intime et politiquement délicat. On regrette d'autant plus le déséquilibre entre la présentation théorique (11 p. sur 17) et le rendu du terrain.

INDEX

Thèmes : 12.1. Iran

\section{AUTEURS}

PHILIPPE ROCHARD

Université Marc Bloch - Strasbourg 